Vuk Miletić ${ }^{1}$

Zoran Ž. Jovanović

Ljiljana Jeremić ${ }^{3}$

High School of Academic Studies “Dositej”, Belgrade
SCIENTIFIC REVIEW ARTICLE

DOI:10.5937/ekonomika1703035M

Received: Jul, 26, 2017

Accepted: September, 08, 2017

\title{
PROGRESSIVE MANAGEMENT SYSTEM - DRIVING DEVELOPMENT AND MANAGING AN ORGANIZATION TOWARDS SUCCESS
}

\begin{abstract}
This paper is exploring the dynamic success of an organization using the analytico-descriptive method in order to accomplish business process improvement by using new ways of work and/or improving work performance. That implies that an organization that tends to be successful encourages the need for changes, it motivates employees to initiate changes and be active members of the process development and organizational culture. The problem is observed through strategic surprises and possible discontinuities when considering strategic complexity as a reason for a management system to exist and function.

To establish a successful management system that drives organization development towards success, the management needs to understand current business trends and set a motivating climate and culture in order to motivate all level personnel to contribute towards success. A quality system of progressive management covers more than the usual processes, initiatives for improvement and projects or documented procedures.
\end{abstract}

Keywords: organization, management system, process, sustainable success.

JEL Classification: M54, M21

\section{ПРОГРЕСИВНИ СИСТЕМ МЕНАЏМЕНТА - ПОКРЕТАЧ РАЗВОЈА И ВОЪЕЊА ОРГАНИЗАЦИЈЕ КА УСПЕХУ}

\begin{abstract}
Апстракт
У раду се аналитичко-дескриптивном методом истражује динамизам успеха организације који носи са собом опцију унапређења пословних процеса, употребом нових начина рада и/или побољшања њених перформанси. То подразумева да се у организацији, која тежи успеху, подстиче потреба за променама, да се запослени мотивишу да иницирају промене, да буду активни учесници у развоју процеса и културе организације у којој је успостављен
\end{abstract}

\footnotetext{
${ }^{1}$ vuk.miletic88@gmail.com

2zojo30@yahoo.com

33 jeremicljiljana@gmail.com
} 
процес управљања променама, као и да се континуирано прати реализација програма унапређења. Проблем се посматра и кроз стратешка изненађења и могуће дисконтинуитете, с обзиром да се стратешка комплексност јавља и као разлог за постојање и функционисање система менаџмента.

Ради успостављања успешног система менаџмента који покреће развој организације ка остваривању успеха, потребно је да њено руководство разуме актуелне трендове пословања, као и успостави климу и културу која мотивише људе на свим нивоима да допринесу остварењу успеха. Квалитетан прогресиван систем менаџмента обухвата више од уобичајеног успостављања процеса, иницијатива за унапређење и пројеката, или документованих процедура.

Кључне речи: организација, систем менаџмента, процес, одрживи успех.

\section{Introduction}

Management has always been a source of impulse and one of key factors that determine the direction of developing orientation for organizations. For organizations to prevail and develop successfully on a complex and demanding market, progressive management systems must be used as well as continuously improved upon. Progressive management systems are a tool for performance and capacity maintainability improvement. At the same time, it is confirmed that there is a need for further understanding for management progressive system synchronization with the current context rather than facts because it's an unavoidable assumption for the strategic orientation of many organizations.

The question of subsistence and sustainable success of an organization is connected to the quality and value of management. Organizations cannot grow and develop just by lowering costs and reengineering. The main segment for aggressive growth is an innovative program that serves as a business function for dynamic product and technology changeability. The main factor is the progressive management system that is guided by a synergy of working technologies, innovation and changes. The point is in future orientation that carries enough problems that could be solved only by ambient results of an innovative climate and by using a progressive management system that is based on quality managing principles.

Future organization managers must accept and positively react to complex challenges facing changing environments. It is clear that there is no sophisticated level of understanding how to conduct many activities and how to manage them. A global environment promotes a need for strategic solutions of forecasted phenomena, for planning and flexibility to limit an uncertain business future. New trajectories can result in discontinued organization events like using new ideas created by research that generate completely new products or processes. The trajectories must be managed efficiently. 


\section{Organization and its sustainable success}

Any organization's sustainable success is located at the epicenter of their management's thinking. [Cho, \& V. Pucik, 2005] The more frequent question is how to measure and assess sustainable success. The fact is that there is no unique recipe or instruction on how to build a quality organization. Organization quality expresses the degree to which the combinination of its unique characteristics enables it to reach market goals.

Unique organization attributes are defined by the organization's business success. Thosse attributes are an organization's and its employees' authentic characteristics. It is necessary for organizations that seek maintainable success to continuously determine their success factors. Value criteria for measuring their successfulness have been changing accordingly with the changes in the business context. [Božilović, Miletić, 2014 p. 36] Today's organization success factors are not only related to the quality of products and services they deliver to their customers. Special value is placed on business continuity, the problem of environmental protection, the health and safety of employees, a socially responsible way of doing business, energy efficiency and so on.

To keep maintainable business continuity [Miletić, Trajković, 2015, p. 453] the organization expects to make new success factors and raise the criteria for success value. Today's world market demands not only to have international business guidance but also to create competitive strategies [Smith, Fingar, 2007] in order to achieve sustainable success.

When creating sustainable success factors it is expected that the organization's top management understands current business trends and can act accordingly to create an encouraging climate and culture that will contribute towards achieving expected performance. Organizational management can raise performance quality by strengthening their identity through vision, mission, culture, value and by using different management systems.

\section{Progressive management system}

To succeed and enlarge the capacity of sustainability on the changing market, organizations must use proper management systems as tools for improving overall performance. The fact is that management technology is the oldest solution for all, including business organization success. [Todosijević, 2015, p. 129]. There is a need for innovative management technology of managing complex dynamic systems to intensify changes. The success of one organization can be made only if there is systematic business process improvement by using new work methods or by improving the organization's performance.

In an increasingly complex business environment, which is less and less predictable, progressive organizations are necessarily developing management systems that ensure their increased willingness to make such changes. This is because long-term planning as a management system based on the extrapolation of the past into the future has no more usable value in the practice of new organizations. Sustainable success of the organization requires strategic planning [Jones, Hill, 2012] and harmonization of the 
level of its quality with a set of specific characteristics. This means that the organization of employees must stimulate the need for change, to actively develop the process of managing and implementing the promotion programs.

The organization must manage change by applying knowledge, methods and techniques of a progressive management system. [Miletić, et. al., 2016, p. 363] A valid management system implies more than the usual establishment of a process or proven practices. Progressive management system is based on the principles of quality management. It supports the use of advanced business strategies, uses the criteria of appropriate work in accordance with business integrity, ensures realization of strategic goals of the organization, initiates innovation and competitiveness, applies various tools for improving business processes, provides the availability of resources for the realization of all goals, and establishes dynamic communication with all interested stakeholders.

It is obvious that the incentive to improving the progressive concept of the management system [Milekić, 2013], was in the saturation and decline in the growth of a number of organizations. It was about accelerating change, that is, organizations entered the "era of discontinuity" in which earlier experience was no longer a reliable enough guide for the future. A successfully established management system starts the development of an organization towards achieving results, in order to achieve the highest level of quality of products and services, ensure the efficiency and effectiveness of business processes and maximize profit. In order to achieve these goals, successful organizations use an extended process model that respects the synergy of various activities and criteria for achieving the quality of the organization as a whole (picture 1).
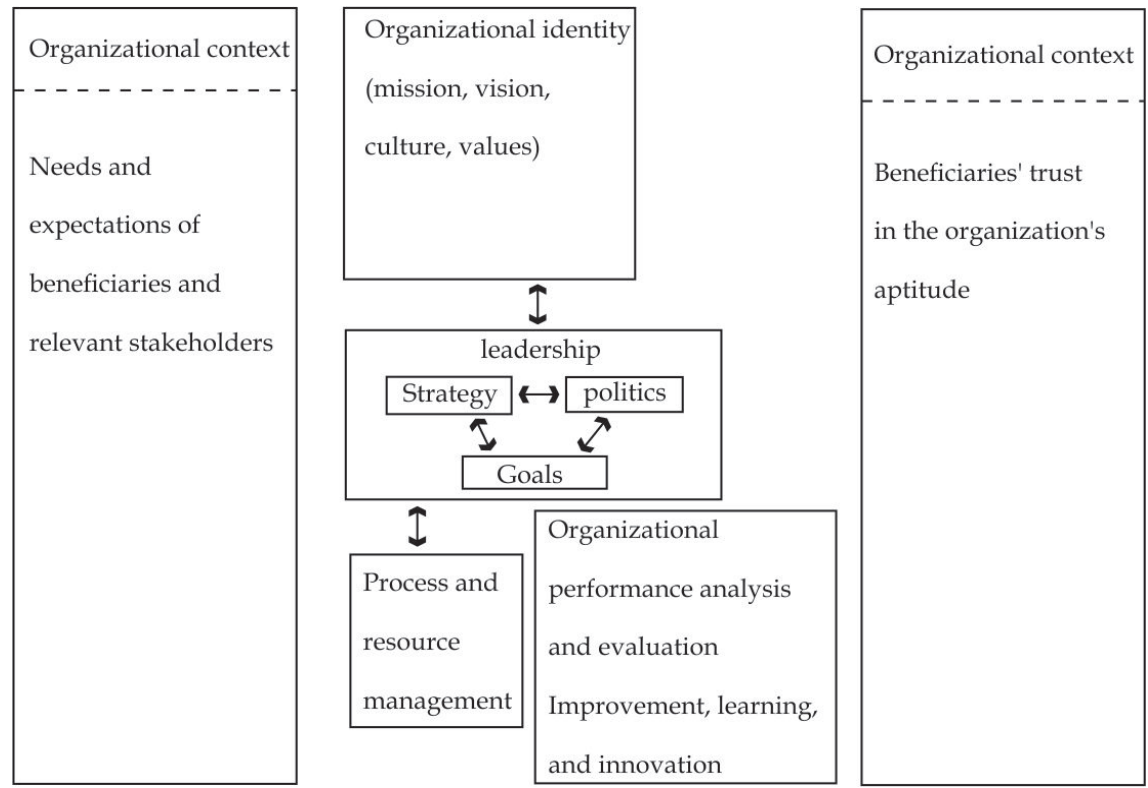

Figure 1. Extended Model Organization Model [18]

It is clear that progressive management systems based on a flexible / fast response appear as a reaction to an increase in the frequency of changes in the organization's 
environment and the conditions in which changes develop so rapidly that strategic time prediction could be applied.

\section{Organization's top management}

It is unnecessary to prove that top management has a decisive role in the process of making a quality and enduringly sustainable organization. It establishes criteria and projects the factors of success, allows achievement of set goals, identifies programs for their realization, delegates responsibility and authorization, provides the necessary resources, valorizes achieved results, continuously encourages improvement, etc. In other words, quality top management is the basis of the profitable functioning of every modern business system.

An initial step in the process of creating a successful organization is that top management assesses the current state of its quality. In order to achieve this goal it is possible to use benchmarking [9], or compare with organizations that produce similar / same products or provide similar / same services. [Rao, A. et. al, 1996, p. 153-4] Different management systems use different criteria, standards and guidelines for self-evaluation (quality, safety, etc.) across different areas of business. The results can be used to collect information about the degree of maturity of an organization.

The motivation of the top management to create a quality organization requires their particular involvement in this process. Exceptional support is essential for the efficient implementation of the management system in the function of attaining the desired quality of the organization. It is the top management who projects expectations, motivates employees to get involved in activities that are triggered in the management system and who approves changes. It should create an atmosphere that encourages employees to actively work on the implementation of the requirements of different management systems, persisting in an effort to realize the projected strategic goals and seek for better solutions than those currently being implemented. This should ensure the confidence of external stakeholders in the sense that the organization uses a successful progressive management system.

Hence, the management team sees the fulfillment of all applicable requirements of the management system as a factor of the organization's success.

\section{Managing organization processes}

Sustainable success is achieved by organizing all necessary activities through an appropriate process. Managing the organization is a process in itself. The purpose of the process is to establish a strategic direction of the organization and to ensure that it realizes its goals. The goal of the process is to achieve sustainability of the organization in a complex environment, with the active participation of all employees. Thus, the success of the process in the organization implies proactive management, using different management mechanisms - regulations, documentation, requirements of MSS standards (ISO / EC that are applicable in practice) [Milovanov, 2014, p. 68], and the engagement of different types of resources [Đuričin, et. al. p. 607-10] (human resources, knowledge, infrastructure, environment, etc.). 
For each identified organization process, the input and output principles (outcomes), including selected constants, performance indicators, performance evaluation methods and process improvement, are determined. The input elements in the process require market analysis, customer satisfaction information, prognoses on the direction of development of applied technology, and so on.

Each of the ongoing processes can be a segment of different management systems. The requirements of the relevant management systems are realized through the business processes of the organization. [Milovanov, 2016, p. 47] One group of the ISO standards [14], determines the quality of products, services in the processes, issues regarding the lack of information in the processes, while for environmental and health issues, other specific requirements of the standards apply.

Through the relevant process in the progressive management system [Lee, et. al., 1999], the requirements of individual management systems are used. Different organizations use different processes. In this regard, the model of a single process (Figure 2) should contain all the enforceable requirements of the standards for management systems.

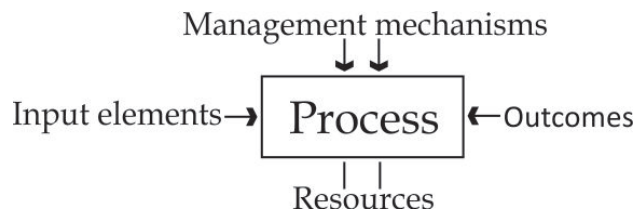

Figure 2.Model of a single process

In order for an organization to manage processes efficiently and effectively, it is necessary to select appropriate criteria [Jeston, Nelis, 2008], in the sense that each unique process is explained in detail. It is about establishing and maintaining a strategy and a policy, a common culture and vision, taking action if results are not achieved, establishing measurable goals, reviewing performance, and more.

In addition to necessary information, in accordance with the standards of the management system that are used and related to the process [Arsovski, 2006], the organization may require other criteria defined based on knowledge of the best practice in a particular business field (for example, dealing with environmental and social impacts, risk taking, periodic performance reports, etc.).

As a result of successful implementation of the organization's management process, it is expected that appropriate criteria of good work and the best business practices have been established and applied.

\section{Conclusion}

In order to ensure that the organization meets and exceeds its set goals, its top management must continuously strive to achieve greater performance and use the best practice relevant to the business / group in which it operates.

Good practice for achieving sustainable business success indicates the need to use adequate standards and guidelines for a progressive management system. Standards 
for management systems provide a valid basis for organizations to set benchmarks for successful business and to achieve high performance.

In the process approach, top management sets the goal for the organization to understand the context in terms of the needs and expectations of all interested stakeholders as a factor of success. It creates confidence in its own ability to meet the expectations of all users, rationally use available resources, and meet all applicable requirements of management mechanisms to the process.

\section{References}

Arsovski S., (2006), Menadžment procesima, Mašinski fakultet, Centar za kvalitet, Kragujevac

Božilović, S. \& V. Miletić, (2014), IMS - Concept(s) of successful leadership organization, 9th International Multidisciplinary Scientific Conference "Eurobrand" Zrenjanin, e-Zbornik radova, p. 35-44

Cho, J. J. \& V. Pucik, (2005), Relationship between innovativeness, quality, growth, profitability and market value, Strategic Management Journal. 26(6); 555-75.

Đuričin, D., S. Janošević, Đ. Kaličanin, (2014), Menadžment i strategija, CID Ekonomskog fakulteta u Beogradu

Jeston, J. \& J. Nelis, (2008), Business Process Management, Elsevier,

Jones, G. R., \& C. W. H. Hill, (2012), Strategic Management Essentials, Third Edition, South-Western, Cengage Learning, Washington

Lee, T., et, al., (1999), Integrated management systems - A Practical Approach to Transforming Organizations, John Wiley \& Sons, Inc., New York

Miletić, S. \& M. Trajković, (2015), Koncept održivog poslovanja - ključni izazov razvoja organizacije,11. Simpozijum savremene tehnologije i privredni razvoj, sekcija: Socijalno ekonomske implikacije novih tehnologija, Tehnološki fakultet Leskovac, e-Zbornik radova p. 451-462.

Miletić, S., S. Borić, et. al., (2016), Integration of Different Management Systems - The Requirement of Successful Management Organization, 7th DQM International Conference ,, Life Cyicle Engineering and Management“, ICDQM, Jun, Prijevor, p. $361-369$

Milekić, M., (2013), Koncepti integrisanih sistema menadžmenta, Kvalitet, Beograd, br. 5-6

Milovanov, B., (2016), Kvalitet organizacije u svetlu novih verzija standarda za sisteme menadžmenta, "Kvalitet” Beograd br. 9-10,

Milovanov, B., 2014, Da li najviše rukovodstvo preuzima ulogu predstavnika rukovodstva shodno novim verzijama standarda za sisteme menadžmenta? "Kvalitet" Beograd br. 1-2,

Rao, A. et. Al (1996), Total Guality Management (A Cross Functional Perspective), John Wiley \& Sons, New York 
Smith, H., P. Fingar, (2007), Business Process Management / The third wave, MeghanKiffer Press,

Simonović Z., (2014), Upravljanje agrarom Srbije u tranziciji, Institut za ekonomiku poljoprivrede, Beograd.

Todosijević, R., (2015), Promene u strategijskom menadžmentu izazvane inovacijama i ključnim tehnologijama, Anali Ekonomskog fakulteta u Subotici, br. 34,

ISO CD 9000:2015] Qualiti management systems - Requirements

ISO CD 9004 Rukovođenje sa ciljem ostvarivanja održivog uspeha organizacije Pristup preko menadžmenta kvalitetom y.com

https://www./search?q=benčmarking+je\&oq=benčmarking\&gs_l=psy-ab.1. (Accessed 25 Jun 2017) 